MATERNAL FRUCTOSE INDUCES GENDER-DEPENDENT CHANGES IN BOTH LXR $\alpha$ PROMOTER METHYLATION AND CHOLESTEROL METABOLISM IN PROGENY by Silvia Rodrigo, Elena Fauste, Maite de la Cuesta, Lourdes Rodríguez, Juan J. Álvarez-Millán1, María I. Panadero, Paola Otero, and Carlos Bocos.

Highlights:

- Maternal fructose modulates gender-dependently LXR $\alpha$ promoter methylation in progeny

- Maternal fructose differentially influences plasma cholesterol in adult offspring

- Maternal fructose affects gender-dependently cholesterol transcriptome in progeny

- Availability of the methyl donor folate might influence $L X R \alpha$ promoter methylation 


\section{MATERNAL FRUCTOSE INDUCES GENDER-DEPENDENT CHANGES IN BOTH LXR $\alpha$ PROMOTER METHYLATION AND CHOLESTEROL METABOLISM IN PROGENY}

Silvia Rodrigo, Elena Fauste, Maite de la Cuesta, Lourdes Rodríguez, Juan J. Álvarez-Millán1, María I. Panadero, Paola Otero, and Carlos Bocos.

Facultad de Farmacia, Universidad San Pablo-CEU, CEU Universities, Montepríncipe, Boadilla del Monte, Madrid, Spain. ${ }^{(1)}$ CQS Lab, Madrid, Spain.

Abbreviations: RCT, Reverse cholesterol transport; LXR $\alpha$, Liver X-receptor alpha; CpG islands, CG-dinucleotide-rich regions in the gene promoter; HDL, High-density lipoproteins; PPAR, Peroxisome proliferator-activated receptor; SRB-1, Scavenger Receptor class B, member 1; ABC, ATP-binding cassette; CYP7A1, cholesterol 7-alpha hydroxylase; LDLR, LDL receptor; HMG-CoA reductase, 3-hydroxy-3-methylglutaryl-CoA reductase; SREBP, Sterol Response Element Binding Protein; Bsep, Bile salt export pump; NTCP, $\mathrm{Na}^{+}$-taurocholate cotransporter polypeptide; Shp, Small heterodimer partner; LRH1, Liver receptor homolog 1; Dnmt, DNA methyltransferase; ACC, Acetyl-CoA carboxylase; FAS, Fatty acid synthase; SCD1; Stearoyl-CoA desaturase.

Key words: Fructose; pregnancy; fetal programming; epigenetics; cholesterol.

\section{Corresponding author:}

Carlos Bocos; Facultad de Farmacia; Universidad San Pablo-CEU, CEU Universities; Urbanización Montepríncipe; 28668 Boadilla del Monte, Madrid, Spain. E-mail: carbocos@ceu.es 


\begin{abstract}
Fructose consumption from added sugars correlates with the epidemic rise in obesity, metabolic syndrome and cardiovascular diseases. However, consumption of beverages containing fructose is allowed during gestation. We have investigated whether maternal fructose intake produces subsequent changes in cholesterol metabolism of progeny. Carbohydrates were supplied to pregnant rats in drinking water $(10 \% \mathrm{w} / \mathrm{v}$ solution) throughout gestation. Adult male and female descendants from fructose-fed, control or glucose-fed mothers were studied. Male offspring from fructose-fed mothers had elevated plasma HDL-cholesterol levels, whereas female progeny from fructose-fed mothers presented lower levels of non-HDL cholesterol versus the other two groups. Liver X-receptor (LXR), an important regulator of cholesterol metabolism, and its target genes such as scavenger receptor B1, ATP-binding cassette (ABC)G5 and cholesterol 7-alpha hydroxylase showed decreased gene expression in males from fructose-fed mothers and the opposite in the female progeny. Moreover, the expression of a number of LXR $\alpha$ target genes related to lipogenesis paralleled to that for LXR $\alpha$ expression. In accordance with this, LXR $\alpha$ gene promoter methylation was increased in males from fructose-fed mothers and decreased in the corresponding group of females. Surprisingly, plasma folic acid levels, an important methyl-group donor, were augmented in males from fructose-fed mothers and diminished in female offspring. Maternal fructose intake produces a fetal programming that influences, in a gender-dependent manner, the transcription factor LXR $\alpha$ epigenetically, and both hepatic mRNA gene expression and plasma parameters of cholesterol metabolism in adult progeny. Changes in the LXR $\alpha$ promoter methylation might be related to the availability of the methyl donor folate.
\end{abstract}




\section{Introduction}

Cardiovascular disease (CVD) is one of the most prevalent diseases in humans. CVD remains the leading cause of death both among Europeans and around the world, responsible for over 4 million deaths per year, close to half of all deaths in Europe [1]. Its origin is multifactorial, two key factors being genetics and the environment. Experimental and epidemiological studies demonstrate that metabolic events during pre- and postnatal development modulate metabolic disease risks in later life [2-4]. This phenomenon is called the Developmental Origins of Health and Disease (DOHaD) hypothesis [5]. Maternal nutritional status has been established as one of the most influential parameters on the health of the adult [6-8] therefore, the notable clinical relevance to address is the relationship between nutrient intake during pregnancy and/or lactation and the metabolic fate of the offspring.

Numerous clinical studies have shown that high fructose intake, present in added sugars such as sucrose and high fructose corn syrup, is linked to obesity, metabolic syndrome and cardiovascular diseases in humans $[9 ; 10]$. Rat is a good model for studying the effects induced by fructose in humans $[11 ; 12]$. In previous studies, rodents fed liquid fructose $(10 \%$ $\mathrm{w} / \mathrm{v}$ ) have shown similar metabolic alterations to those found in clinical reports $[11 ; 13 ; 14]$. In fact, this concentration of fructose supplementation is very close to that of sugar-sweetened beverages, and the total amount of calories obtained from simple sugars in those studies is similar to the daily energy intake from simple sugars observed in heavy consumers of sweetened beverages in human populations [15]. Thus, despite the connection between a greater consumption of fructose-containing beverages and the increase in the prevalence of diabetes, obesity and cardiovascular diseases having been established, intake of these beverages and fruit juices is allowed during gestation and/or lactation.

Therefore, we investigated the effects of a low fructose intake $(10 \% \mathrm{w} / \mathrm{v})$ throughout gestation in mothers and their fetuses [16], and we found that fetuses from fructose-fed mothers displayed an impaired transduction of the leptin signal, and that these findings were not observed in glucose-fed rats. Furthermore, we demonstrated that the fructose intake throughout gestation has long-term consequences on the offspring. Thus, we have concluded that the maternal intake of fructose throughout gestation produces a number of features in male adult progeny that are typically found in metabolic syndrome, including impaired insulin signalling and a slight accretion of hepatic triglycerides [17]. Interestingly, female progeny 
born of fructose-fed mothers showed none of these characteristics unless they were exposed to liquid fructose when adults and then, clear dyslipidemia and liver steatosis were observed $[18]$.

An increasing number of studies demonstrate that maternal nutrition produces epigenetic changes which are responsible for the development of metabolic diseases in adult progeny $[5 ; 19 ; 20]$. One of the most relevant epigenetic mechanisms is DNA methylation. If this methylation affects the gene promoter, gene expression will be modified and, generally, an inverse correlation between both parameters will be found [19]. Thus, for example, Lillycrop et al reported that a poor maternal nutrition status induces hypomethylation and upregulation of PPAR $\alpha$ gene expression in liver of offspring [21]. On the other hand, Laker et al described lower mRNA expression of PGC1 $\alpha$ and its target genes and upper promoter methylation in progeny from mothers fed a high-fat diet [22]. In this same sense, Yu et al found that a maternal high-lipid, high-energy diet produced hypermethylation of PPAR $\gamma$ and LXR $\alpha$ gene promoters and decreased the expression of these genes in offspring [23]. Related to this, van Straten et al observed that the promoter of $\operatorname{LXR} \alpha$ gene was hypermethylated in male offspring from dams fed a protein-restricted diet during gestation [24]. These changes interfered with fetal lipid metabolism and, more specifically, with cholesterol metabolism. Another report linking maternal nutrition, cholesterolemia and increased CVD risk in the offspring has been described in rats by del Bas et al [25]. Since it has been proved that chronic fructose intake [26] to male rats directly increases promoter CPT1 $\alpha$ and PPAR $\alpha$ genes methylation, it was expected that maternal fructose intake would produce changes in gene methylation of the offspring, as has recently been described by Yamazaki et al [27]. These authors demonstrated that liquid fructose (at $20 \% \mathrm{w} / \mathrm{v}$ ) given to mothers during gestation and lactation produced an increased methylation at the BDNF promoter in the hippocampus and impaired cognitive performance in the offspring. Nevertheless, there are no reports in the literature which have investigated whether maternal fructose intake affects DNA methylation of genes involved in lipid metabolism in the progeny. All these investigations reinforce the urgent need to address the relationship between maternal nutrient intake, the epigenetic changes and the metabolic fate of the progeny.

High consumption of fructose, especially in the form of sugar-sweetened beverages, has been related to a greater risk of developing CVD [10;28]. We and other authors have demonstrated in rodents that maternal fructose intake leads to dyslipidemia, hepatic steatosis and other risk factors for CVD in the progeny $[17 ; 18 ; 29 ; 30]$ and, moreover, all these effects were 
found to be clearly gender-dependent. Therefore, we wanted to know if consumption of liquid fructose during pregnancy could provoke some kind of fetal programming that affects plasma cholesterol and hepatic mRNA gene expression of cholesterol metabolism in adult progeny, bearing in mind that plasma cholesterol is an evident CVD risk factor.

Since LXR $\alpha$ is an important transcription factor in the regulation of cholesterol metabolism and, further, is also a target of differential methylation [24], the current report is a follow-up study to investigate the effects of maternal liquid fructose on cholesterol metabolism and LXR $\alpha$ gene promoter methylation and its expression in progeny when adult. In contrast to other reports $[29 ; 31 ; 32]$, our model of maternal liquid fructose intake is confined to the prenatal stage and compares the effects of fructose versus glucose-supplementation to demonstrate that the effects are specific of fructose. Moreover, contrary to other studies [27; 31], we used a low dose of fructose $(10 \% \mathrm{wt} / \mathrm{vol})$ that is quite comparable to the concentration contained in soft drinks [15], which reinforces the clinical relevance of the present findings. And finally, another remarkable difference to other reports where epigenetic changes due to diverse dietary treatments were analyzed [21;23-25;27], is that we studied both male and female progeny and at a period of life much longer than many other studies.

\section{Materials and methods}

\subsection{Animals and experimental design}

An animal model of maternal liquid fructose intake was developed as previously described [16; 17]. Briefly, female Sprague-Dawley rats weighing 200-220 g were fed ad libitum standard rat chow (B\&K Universal, Barcelona, Spain) and housed under controlled light and temperature conditions (12-h light-dark cycle; $\left.22 \pm 1^{\circ} \mathrm{C}\right)$. The experimental protocol was approved by the Animal Research Committee of the University San Pablo-CEU, Madrid, Spain. Animals were mated, and day 0 of pregnancy was determined by the appearance of spermatozoids in vaginal smears. Then, the animals were randomly separated into a control group, a fructose-supplemented group, and a glucose-supplemented group (six rats per group). Fructose and glucose were supplied as a $10 \%(\mathrm{w} / \mathrm{v})$ solution in drinking water throughout gestation. Control animals received no supplementary sugar. Pregnant rats were allowed to deliver and on the day of birth, each suckling litter was reduced to nine pups per mother, and we tried to leave similar number of males and females. After delivery, both mothers and their pups were maintained with food and water ad libitum. It is remarkable that these animals (mothers and pups) received no subsequent additive in the drinking water. On the $21^{\text {st }}$ day after delivery, the 
lactating mothers were removed to stop the suckling period and pups were separated by gender. One male (or female) pup (with median body weight) was selected from each litter. In order to minimize the "litter effect", animals within each experimental group were born to different dams. When the progeny were 261-day-old, they were sacrificed and blood collected using tubes containing $\mathrm{Na}_{2}$-EDTA. Liver was immediately removed, placed in liquid nitrogen and kept at $80{ }^{\circ} \mathrm{C}$ until analysis. Samples were then centrifuged, and plasma was stored at $-80{ }^{\circ} \mathrm{C}$ until processed for subsequent determinations. The rest of each litter was used for a separate experiment.

\subsection{Determinations}

Plasma aliquots were used to measure total and HDL cholesterol, and bile acids using commercial enzymatic colorimetric test kits (Spinreact, Girona, Spain). Non-HDL cholesterol was calculated by subtraction of HDL cholesterol from total cholesterol levels. An enzymatic kit using chemiluminescent immunoanalysis on microparticles (Architect, Abbot Ireland) was used for the quantitative determination of folic acid in plasma.

Two hundred milligrams of frozen liver were immersed in chloroform:methanol 2:1 plus dibutylhydroxytoluene (BHT), and used for lipid extraction following the Folch method [33]. Aliquots of lipid extracts were dried and the remaining residue redissolved in isopropanol and used to determine cholesterol as mentioned above.

\subsection{Total RNA preparation and analysis}

Total RNA was isolated from liver using Ribopure (Ambion Inc., USA). The 260/280 absorption ratio of all samples was between 1.8 and 2.0. Total RNA was subjected to DNase I treatment using Turbo DNA-free (Ambion Inc., USA), and RNA integrity was confirmed by agarose gel electrophoresis. Genomic DNA contamination was discarded by PCR using primers for ribosomal protein S29 (Rps29), resulting in a negative reaction. After, cDNA was synthesized by oligo(dT)-primed reverse transcription with Superscript II (Invitrogen, USA). qPCRs were carried out using a Light Cycler 1.5 (Roche, Germany). The reaction was performed in a volume of $20 \mu \mathrm{l}$, containing $10 \mathrm{pmol}$ of both forward and reverse primers, $10 \mathrm{x}$ SYBR Premix Ex Taq (Takara Bio Inc., Japan) and appropriate nanograms of the cDNA stock. Rps29 was used as a reference gene for qPCR. The sense and antisense primer sequences were obtained either from Atlas RT-PCR Primer Sequences (Clontech, CA, USA) or designed using Primer3 software (University of Massachusetts Medical School, USA) [34]. 
Samples were analyzed in duplicate on each assay. Amplification of non-specific targets was discarded using the melting curve analysis method for each amplicon. qPCR efficiency and linearity were assessed by optimization of standard curves for each target. The transcription was quantified with Light Cycler Software 4.05 (Roche, Germany) using the efficiency correction method [35].

\subsection{Determination of percentage of methylation of LXR gene promoter}

DNA methylation analysis was assessed using restriction digestion and Real Time PCR, as described previously [36]. Hepatic DNA was isolated with DNeasy Blood and Tissue Kit (Qiagen Inc, Hilden, Germany). Genomic DNA was digested in separate reactions with or without the methylation-dependent restriction enzyme (MDRE), McrBC (Takara Bio, USA). Regions rich in $\mathrm{CpG}$ were identified in gene promoters using MethPrimer software [37]. Primers were designed to flank both restriction sites of interest and a control region by Primer3 software [34]. As a control region, a sequence in the glucocorticoid receptor promoter which contained no $\mathrm{CpG}$ and no $\mathrm{McrBC}$ recognition sites was chosen and control primers designed. Individually digested DNA samples were amplified using the Light Cycler 1.5 (Roche, Germany), as mentioned above. PCR amplification was initially performed using the control primers to ensure that the templates were of equal concentration and that nonspecific cleavage of the DNA sample had not occurred. Acceptable variability in mean template $\mathrm{Ct}$ values range from \pm 0.3 cycles [36]. Once it had been confirmed that all of the templates fell within the acceptable range, $\mathrm{Ct}$ values were then obtained using the primers designed for the region of interest. Shifts in the $\mathrm{Ct}$ values $(\Delta \mathrm{Ct})$ of the enzyme-digested samples were expressed relative to the sham-digested samples and used to calculate the percentage of methylation at the $\mathrm{CpG}$ sites within the amplified region. Thus, for MDRE, the relationship of $\Delta \mathrm{Ct}$ to percentage of methylation is obtained using the formula: $\%$ methylation $=100\left(1-\mathrm{e}^{-0.7(\Delta \mathrm{Ct})}\right)$. All $\Delta \mathrm{Ct}$ values are the means of triplicate reactions. Percentage of methylation values obtained were in the expected order of magnitude [26]. In order to confirm our results, we first followed this procedure for the CPT1 gene promoter. Two regions rich in CpG were identified, and an inverse relationship betweeen DNA methylation and gene expression was observed, as had previously been reported [26]. For the LXR $\alpha$ gene, primers used to analyze genomic regions, postulated $\mathrm{CpG}$ islands and the structure of the rat promoter are shown in Figure 1. 


\subsection{Statistical analysis}

Results were expressed as means \pm S.E and analyzed by two-way analysis of variance (ANOVA), with maternal diet (D) and adult progeny gender $(\mathrm{G})$ as factors. Data that were not normally distributed were log transformed to achieve data normality. Then, the Bonferroni test was used for post hoc analysis to identify the source of significant variance. A value of $p$ $<0.05$ was considered statistically significant and if a borderline significant value was found, it was indicated. The eta ${ }^{2}\left(\mathrm{y}^{2}\right)$ parameter was also provided to determine the proportion of the total variance that was attributed to the corresponding effect (D, G or the GxD interaction). All statistical valuation was performed using SPSS version 23 computer program.

\section{Results}

\subsection{Ingestion of a $10 \% \mathrm{w} / \mathrm{v}$ fructose solution throughout gestation affects cholesterol metabolism in adult progeny in a gender-dependent manner}

As we previously reported [16], maternal chow food intake was decreased in carbohydrate-supplemented dams but it was compensated for with an increase in the total fluid consumption (sugary waters) [16]. Thus, total caloric intake was not significantly different between the three groups $(1826 \pm 69,2084 \pm 120,2358 \pm 243 \mathrm{kcal} / \mathrm{rat}$ for control, fructose-fed and glucose-fed pregnant rats, respectively [16]). Fructose intake accounted for approximately $25 \%$ of total caloric intake, whereas glucose represented around $35 \%$ [15].

Moreover, we have previously reported that fructose intake throughout pregnancy did not produce any change in the body weight of the adult male and female progeny. Male and female rats from fructose-fed mothers showed no differences in the ingestion of liquids nor the amount of ingested solid food in comparison to the descendants from the other two groups [17]. Neither male nor female rats showed any differences in plasma non-esterified fatty acids, glycerol, triglyceride and 17 $\beta$-estradiol (for females) concentrations [17].

As shown in Table 1 , there was a significant interaction $(p=0.009)$ between the effects of diet and gender in plasma total cholesterol. Therefore, it was slightly augmented in males from carbohydrate-fed mothers and diminished in female progeny from fructose-fed mothers [38]. In fact, Bonferroni's post hoc analysis demonstrated significant decreased levels in females from fructose-fed mothers in comparison to males $(p<0.05)$ and almost significant decreased levels versus females from control mothers $(p=0.061)$. The reason for this situation would be in the HDL-cholesterol. Whereas non-HDL cholesterol was similar among the three experimental groups and between genders, plasma HDL cholesterol levels 
were higher in male descendants from fructose-fed rats (around $+18.5 \%$ for offspring of fructose-fed dams versus progeny from the other two groups) and significantly different ( $\mathrm{p}<$ 0.05) in comparison to females from fructose-supplemented rats. Total cholesterol content in liver tended to be higher in progeny from carbohydrate-fed rats, becoming significant in those animals from glucose-fed mothers (Table 1).

According to these findings, the expression of several components of the reverse cholesterol transport (RCT) in liver, such as scavenger receptor class B, member 1 (SRB1), cholesterol transporter ATP-binding cassette G5 (ABCG5) and cholesterol 7-alpha hydroxylase (CYP7A1) showed the effect of sex and, mainly, a clear gender and diet interaction, where fructose prenatal exposure diminished mRNA expression of RCT genes in adult male rats but increased it in females (Figure 2). More precisely, Bonferroni's post hoc analysis indicated that fructose intake in pregnancy produced a significant decrease $(p<0.05)$ in SRB1 gene expression in male progeny versus glucose-fed group, and a significant increase $(\mathrm{p}<0.05)$ in ABCG5 mRNA levels in female progeny in comparison to the control group (Figure 2). Moreover, we observed significant differences in the mRNA levels of SRB1 and ABCG5 between female and male progeny from control and glucose-fed mothers, but not from fructose-supplemented dams. Thus, the differences in SRB1 and ABCG5 due to gender were attenuated in progeny from fructose-fed mothers. Nevertheless, the most prominent changes were observed for CYP7A1 gene expression. Males from fructose-fed dams displayed lower mRNA gene expression than the other two groups $(\mathrm{p}<0.05$ and $\mathrm{p}=0.058$, versus progeny from control and glucose-fed mothers, respectively) and females from fructose-fed mothers showed significantly higher levels than females from glucosesupplemented dams $(\mathrm{p}<0.05)$ (Figure 2).

Genes involved in cholesterol biosynthesis and uptake, such as sterol response element binding protein 2 (SREBP2), LDL receptor (LDLR), and 3-hydroxy-3-methylglutaryl-CoA reductase (HMGCoA reductase) demonstrated no effect for sex, or diet, although we observed a gender and diet interaction (Figure 3). Thus, fructose prenatal exposure significantly decreased SREBP2 mRNA gene expression in males versus progeny from control mothers ( $p$ $<0.05)$, and significantly increased it in females versus offspring from control $(\mathrm{p}<0.05)$ and glucose-fed mothers $(p=0.059)$. However, this profile observed for the transcription factor SREBP2 was only partially found for one of its target genes, LDLR, but not for HMG-CoA reductase. Thus, LDLR mRNA levels were significantly decreased in males from fructose-fed 
pregnant rats in comparison to the other two groups $(\mathrm{p}<0.05$ and $\mathrm{p}=0.078$, versus control and glucose groups, respectively) (Figure 3).

Surprisingly, plasma bile acids levels exhibited the effect of sex and a clear diet and gender interaction $(\mathrm{p}=0.002)$, where fructose prenatal exposure increased plasma bile acids in males but decreased them in females (Table 2). In fact, Bonferroni's post hoc test demonstrated that whereas female and male progeny from control and glucose-fed mothers were significantlly different, it was not the case in the offspring from fructose-supplemented dams. Thus, the differences in plasma bile acids levels due to gender, disappeared in progeny from fructose-fed pregnant rats. This finding contrasts to that found for CYP7A1, the gene codifying by the key enzyme in bile acids synthesis (Figure 2). Therefore, bile acids could be acting as regulators of their own synthesis. However, no effects due to gender, diet or interaction were found in other genes involved in bile acids synthesis, liver entry and excretion, such as Bile salt export pump (Bsep), $\mathrm{Na}^{+}$-taurocholate cotransporter polypeptide (NTCP), Small heterodimer partner (Shp) and Liver receptor homolog 1 (LRH1) (Table 2).

\subsection{Maternal intake of a $10 \% \mathrm{w} / v$ fructose solution affects methylation of LXR $\alpha$ gene promoter and its function in adult progeny in a gender-dependent manner}

Liver $\mathrm{X}$ receptor alpha $(\mathrm{LXR} \alpha)$ is an important nuclear receptor involved in cellular cholesterol, bile acids and fatty acids homeostasis. It has been demonstrated that the LXR $\alpha$ promoter can be more or less methylated, affecting its expression and role as a transcription factor. In fact, that the hypermethylation of LXR $\alpha$ gene promoter is accompanied with a diminished LXR $\alpha$ expression and a clear reduction of its target genes expression has been described in male fetuses of a mouse model of prenatal protein restriction [24].

Therefore, one of the most important aims of the present work was to determine whether the ingestion of a fructose solution $(10 \% \mathrm{w} / \mathrm{v})$ by pregnant rats throughout gestation would modify the methylation status in the promoter of the gene codifying by LXR $\alpha$ in adult progeny. A further objective was to demonstrate whether this differential methylation could also be affecting the transcription factor functioning and, more interestingly, to confirm that it is a gender-dependent effect.

Strikingly, promoter methylation of LXR $\alpha$ gene demonstrated the effects of sex and diet and, moreover, a clear gender and diet interaction $(\mathrm{p}<0.001)$, where maternal fructose intake produced an increase in LXR $\alpha$ methylation in males and a decrease in LXR $\alpha$ promoter 
methylation in females (Figure 4). Thus, post hoc analysis displayed significant differences ( $\mathrm{p}$ $<0.05)$ for males from fructose-fed mothers in comparison to the other two groups. Furthermore, only females from fructose-fed dams showed significant differences $(p<0.05)$ versus the corresponding group of diet in males (Figure 4). It is widely accepted that an inverse correlation exists between promoter methylation and transcription of the corresponding gene $[19 ; 24 ; 26]$. In accordance with this, the profile for LXR $\alpha$ gene expression was the complete opposite of that found for LXR $\alpha$ promoter methylation. In fact, LXR $\alpha$ mRNA levels demonstrated to be affected by sex and a diet and gender interaction $(\mathrm{p}<$ 0.001) was found. Thus, whereas it was markedly reduced in male progeny of fructose-fed mothers (Figure 4), LXR $\alpha$ gene expression of female descendants from fructosesupplemented rats was significantly augmented versus the other two groups $(\mathrm{p}<0.05)$.

Moreover, in parallel with the observed changes in the levels of LXR $\alpha$ gene expression (Figure 4), its target genes showed a similar profile in their expression (Table 3). Thus, expression of lipogenic genes (SREBP1c, ACC and FAS) displayed the effects of sex, diet and the interaction of gender and diet (Table 3). Furthermore, gene expression of the cholesterol transporter ATP-binding cassette A1 (ABCA1) also demonstrated a diet and gender interaction (Table 3). These findings were in consonance to those mentioned above for other known LXR $\alpha$ target genes such as ABCG5, SRB1 and CYP7A1 [39-41] (Figure 2). However, gene expression of PPAR $\alpha$ (which is not known to be a LXR $\alpha$ target gene) was not influenced by gender or maternal intake (Table 3).

Once it was demonstrated that maternal fructose intake affects promoter methylation of the LXR gene, the expression of the genes responsible for DNA methylation, that is, the mRNA gene expression encoding DNA methyltransferase-1, $-3 a$, and $3 b$ was determined. While Dnmt1 and Dnmt3b gene expression exhibited a diet and gender interaction, Dnmt3a was not shown to be affected by gender, diet or both (Table 3). Bonferroni's post hoc analysis demonstrated that whereas there were no differences between the three groups in males for Dnmt1 gene expression, females from fructose-fed mothers showed a marked increase $(p<$ 0.05 ) in comparison to the other two groups. However, for Dnmt3b expression, male progeny from fructose-fed dams demonstrated a significant decrease $(p<0.05)$ versus the control group (Table 3).

\subsection{Ingestion of a $10 \% \mathrm{w} / \mathrm{v}$ fructose solution throughout gestation affects in a gender- dependent manner plasma folic acid levels in adult progeny}


The LXR $\alpha$ promoter hypermethylation found in male from fructose-mothers (Figure 4) could be due to an upregulation of DNA-methyltransferases genes expression. However, a diminished expression was found for Dnmt3b in the male progeny from fructose-fed mothers (Table 3). Hence, the effect observed in the LXR $\alpha$ gene promoter could be due instead to an excess of methyl group availability. In contrast, female descendants from fructose supplemented rats showed a decrease in LXR $\alpha$ promoter DNA methylation, and this finding did not correlate to a downregulation of DNA-methyltransferases, since the Dnmt1 gene expression was augmented in that group (Table 3). Therefore, plasma levels of one of the most important methyl group donors (folic acid) were measured.

Folic acid levels were not affected by sex or diet; however, surprisingly, we observed a maternal diet and gender interaction $(\mathrm{p}=0.025)$, indicating that fructose prenatal exposure augmented folic acid in males but decreased it in females (Figure 5). In fact, post hoc test showed a significant difference $(\mathrm{p}<0.05)$ only between males and females from fructose-fed pregnant rats.

\section{Discussion}

Based on the present results, one might think that it would be beneficial for the progeny if the mother ingested liquid fructose during pregnancy. Thus, in males from fructose-fed mothers, HDL cholesterol levels were increased. And females from fructose-fed mothers presented a clear hypocholesterolemia possibly due to the non-HDL cholesterol levels which tended to be lowered in comparison to the other two groups. Both cholesterolemia and HDL cholesterol are good predictors of CVD [25]. It is well known that HDL contributes to the elimination of cholesterol from peripheral tissues by reverse cholesterol transport (RCT) into the luminal intestine by passing through the liver and transforming into bile acids [25]. Therefore, HDL cholesterol levels are considered as a protective factor against CVD.

However, when gene expression of RCT components in liver were studied, SRB1, the main receptor of HDL and CYP7A1, the key enzyme for bile acids synthesis, were significantly reduced in male progeny from fructose-fed mothers suggesting an impaired reverse transport and excretion of cholesterol. Possibly, then, cholesterol was being correctly removed from peripheral tissues but, the final part of RCT (the one that takes place in the liver) was not working appropriately in males from fructose-fed mothers. In addition to this 
impaired entry of cholesterol into the liver, LDLR gene expression was also reduced. In contrast to males, CYP7A1 mRNA expression and ABCG5, a cholesterol transporter to the bile, were augmented in females from fructose-fed mothers versus the other groups, indicating an increased elimination of cholesterol by means of both bile acids and direct excretion of cholesterol into bile. This situation would explain the hypocholesterolemia observed in this group. Further, up-regulation of CYP7A1 has previously been related to an improvement of atherogenic risk indexes $[25 ; 40]$.

Interestingly, bile acids levels were increased in male offspring from fructose-fed dams $(+82 \%$ and $+58 \%$ versus progeny from control and glucose-fed mothers, respectively). It is known that bile acids are able to regulate their own synthesis in the liver by activating the bile acid receptor farnesoid X receptor (FXR) and inhibiting CYP7A1 hepatic gene expression [39]. However, mRNA expression of other FXR-target genes, such as Bsep, NTCP and Shp, were not affected in males from fructose-fed dams, proving that FXR is not involved. Further, LRH1 gene expression, which heterodimerizes with Shp to inhibit CYP7A1 expression, was also unaltered [39; 40]. Moreover, increased bile acids levels could be due to higher ileal reabsorption. This situation would be accompanied by an increase in fibroblast growth factor 15 (FGF15) intestinal synthesis and secretion [40] in order to block hepatic CYP7A1 and synthesis of more bile acids. It has recently been shown that FGF15 also stimulates hepatic glycogen synthesis [42]; however, liver glycogen content was similar for the three experimental groups of male rats in the present study (data not shown).

In contrast, bile acids levels were decreased in female offspring from fructose-fed mothers. However, FXR-target genes expression in female progeny was again unaffected by maternal diet. LRH1 gene expression and hepatic glycogen content were not modified, discarding FXR and FGF15 implication.

Both SREBP2 and LXR are transcription factors that work together in liver to regulate cholesterol metabolism [40]. SREBP2 could help us elucidate the action mechanism of the maternal fructose-induced long-term changes here observed. However, although its expression was reduced in male offspring from fructose-fed mothers, only its target gene LDLR responded in the same way, without any effect in HMG-CoA reductase expression. This lack of response of the SREBP2 target genes to changes in the expression of this nuclear receptor was also found in the livers of females from fructose-fed dams, confirming that SREBP2 is not the transcription factor orchestrating cholesterol metabolism in the present study. 
Interestingly, LXR is a nuclear receptor critically involved in the control of cholesterol and fatty acid metabolism. LXR has been described as one of the metabolically most interesting DNA methylation-sensitive genes [24]. The relation between LXR $\alpha$ promoter methylation and its gene expression has been previously demonstrated [24]. In fact, van Straten et al found hypermethylation of LXR $\alpha$ promoter, decreased LXR and target genes expression and affected fetal cholesterol metabolism in male fetuses of mice submitted to a maternal protein-restricted diet. Moreover, hypermethylation of LXR promoter and lower hepatic LXR $\alpha$ protein expression in male adult mice born to mothers that consumed a high lipid and high energy diet during gestation and lactation have also been reported [23].

Thus, in our model, we found a hypermethylation of $\operatorname{LXR} \alpha$ promoter accompanied a lower expression of this nuclear receptor in males from fructose-fed mothers, versus the other two groups. Remarkably, the opposite situation was found in female progeny compared to the male offspring. Percentage of methylation of the LXR $\alpha$ gene promoter in females from fructosesupplemented dams was only $1.8 \%$ of the value for the control group and $4.2 \%$ of the data observed for the glucose-fed group. Furthermore, this hypomethylation was accompanied by a higher LXR $\alpha$ gene expression. These findings would explain the contrary results found for males and females from fructose-fed dams in the expression of a number of well-characterized LXR target genes involved in cholesterol metabolism, such as SRB1, ABCG5 and CYP7A1 [41]. Furthermore, LXR has also been involved in the control of fatty acid synthesis by regulating the expression of lipogenic genes, such as SREBP1c, ACC and FAS [24; 39; 40; 43]. Accordingly, the expression of these lipogenic genes was significantly decreased in males and increased in females from fructose-fed mothers, versus the other two groups. Therefore, LXR $\alpha$ is the nuclear receptor that regulates the gender-dependent effects found here in cholesterol (and fatty acid) metabolism in offspring from fructose-fed dams.

LXR $\alpha$ expression is controlled by several nuclear receptors, including: PPAR $\alpha$, PPAR $\gamma$ and STAT3 [44; 45]. In the present study, neither PPAR $\alpha$ (Table 3) nor PPAR $\gamma$ (data not shown) mRNA levels displayed differences between the three groups in male and female progeny. Moreover, protein levels of suppressor of cytokine signaling-3 (SOCS3), whose expression is regulated through STAT3 activation [46], were similar for the three groups in male and female offspring (data not shown). Thus, the significant changes described here for LXR $\alpha$ mRNA levels with maternal fructose intake, in both males and females, were due not to variations in repressors and activators of LXR $\alpha$ expression, but to the modifications in the methylation of its promoter. 
In addition, it has been demonstrated that the methylation state of LXR $\alpha$ promoter fine-tunes the normal physiologic regulation of the gene [45], modulating its ability to respond to signals such as insulin, leptin, TNF $\alpha$, etc, and therefore, influencing its downstream fatty acid and cholesterol metabolic pathways, as we have previously established for hepatic lipogenesis [17].

Lillycrop et al proposed that a lack of methyl group donors, together with adaptations in DNA-methyl transferases, could provoke a global DNA hypomethylation to explain the lower methylation found in hepatic PPAR $\alpha$ promoter of offspring born to protein-restricted mothers [47]. However, van Straten et al also observed hypomethylation in LXR $\alpha$ promoter in a mouse model of prenatal protein restriction, but no compensatory upregulation of the three Dnmts measured was found [24]. Furthermore, Lillycrop et al have reported that DNA hypomethylation, and subsequent changes in gene expression, might be prevented with folic acid supplementation $[21 ; 47]$.

Interestingly, in our model, males from fructose-fed mothers tended to show higher plasma folic acid levels than male offspring from the other two groups. A higher disposal of this methyl-group donor could be producing a hypermethylation of the $\operatorname{LXR} \alpha$ gene promoter and a down-regulation in the DNA-methyl transferases expression as a compensatory mechanism, as we have found in the present study. Contrary to this, female progeny born of fructose-fed mothers tended to display a decrease in plasma folic acid levels, accompanied by a reduction of LXR gene promoter methylation and a compensatory up-regulation of Dnmt 1 gene expression. It has been reported that a diminution of plasma folate increases plasma homocysteine and decreases DNA methylation [48], and females from fructose-fed mothers presented increased plasma homocysteine versus the other two groups $(15.8 \pm 2.6,26.6 \pm 3.5,21.6 \pm 3.1 \mu \mathrm{M}$ for female offspring from control, fructose- and glucose-fed dams, respectively; $+68 \%$ and $+23 \%$, for progeny of fructose-fed mothers versus control and glucose groups). Pregnancy is a period that demands increased folate intake. Folates are needed for fetal growth and placental development [49]. Therefore, pregnancy in females born to fructose-fed mothers, which already present low folate levels, could produce a severe lack of folate, which is essential during pregnancy. At least in Spain, only three percent of women have an adequate folate intake in their diet [50]. Therefore, the widespread ingestion of beverages containing fructose by adults worlwide, including reproductively active individuals, reinforces the notable clinical relevance of the observations obtained in the present study.

Curiously, the profile for plasma folic acid levels found here, higher in male and lower in female progeny of fructose-fed mothers in comparison to the other two groups (Figure 5), 
resembles that observed for plasma bile acid levels (Table 2). Folates, like bile acids, are subjected to an enterohepatic cycle that also includes biliary excretion [51]. In addition, although folates are water-soluble vitamins, several reports have suggested that bile acids might be involved in folate and vitamin- $\mathrm{B}_{12}$ absorption $[52 ; 53]$. Therefore, the idea that some components of the enterohepatic cycle in offspring could have been affected by maternal fructose intake should not be discarded. In fact, dietary fructose has been reported to affect the intestinal barrier [54], and carbohydrate consumption has been shown to influence folate absorption and bacterial folate production in the small intestine [55]. Moreover, folic acid-supplementation has been related to lower CYP7A1 mRNA expression [56], and we observed a clear diminution of CYP7A1 gene expression in males from fructose-fed dams.

The present findings demonstrate for the first time that maternal fructose, but not glucose, intake influences cholesterol metabolism in adult progeny by affecting DNA methylation and expression of $\operatorname{LXR} \alpha$ and, more interestingly, in a gender-dependent manner. Since the rats studied here were almost nine months of age and had never received fructose, we can surmise that maternal fructose consumption produces some kind of fetal programming with long-term consequences on metabolic regulation. These results observed for LXR $\alpha$ in adulthood would be in consonance to those reported by Lillycrop [47] for PPAR $\alpha$, but in disagreement to Yamazaki et al [27], who observed that changes in DNA methylation of BDNF only lasted until maturity. To clarify all of this, Yuan et al [57] have reported that the duration of the epigenetic memory may vary from one gene to another, and this is dependent on the level of DNA methylation reached when the epigenetic mark was established.

In addition to the sex differences in epigenetics, some other potential mechanisms that could also be involved in the different metabolic effects observed here between genders, would be: the genetic sex, the programming effect of testosterone in the prenatal period, how the placenta responds to different stimulus [58], and the role of sex hormones at puberty [59]. For example, female sex hormones have been demonstrated to confer protection against the effect of nutrients in various situations [60]. Even a sex-specific association has been described between uric acid and the risk of being affected with metabolic diseases [61]. However, uricemia was similar for the three experimental groups in male and female rats in the present study (data not shown).

Interestingly, the alterations in LXR $\alpha$ and cholesterol metabolism found here might be even more exacerbated by exposing these animals when adults to a high-fat or cholesterol-rich diet $[62 ; 63]$. Nonetheless, one limitation of our study that could be addressed in the future is that 
we used simple sugars (glucose and fructose) instead of sucrose or high fructose corn syrup (HFCS). It is known that the presence of both fructose and glucose in the same solution favors the absorption of both sugars and has a synergistic metabolic effect. In our study, maternal fructose intake accounted for approximately $25 \%$ of total caloric intake, a value quite similar to one observed in other animal models of maternal high-fructose intake [64] and very close to the daily energy intake from fructose observed in many consumers of sweetened beverages in human populations [15].

It is noteworthy that DNA methylation has recently been confirmed in a human study as a mediator of the association between prenatal adversity and risk factors for metabolic disease in adulthood [65]. Therefore, the present study would recommend a drastic reduction in the consumption of fructose sweetened beverages during pregnancy to combat the epidemic of metabolic syndrome affecting the human population.

\section{Acknowledgements}

The authors thank Jose M. Garrido and his team for their help in handling the rats, and Brian Crilly for his editorial help. This work was supported by grants from the Ayuda a Grupo en Consolidación from Universidad San Pablo-CEU and Banco de Santander (USP-BSPCON02/2016), and "Manuel de Oya" Award for Nutrition Research-2016 from Fundación Española de Arteriosclerosis/Sociedad Española de Arteriosclerosis (FEA/SEA). Silvia Rodrigo was supported with a FUSP-CEU fellowship. Elena Fauste is supported with a FPU fellowship from Ministerio de Educación, Cultura y Deporte.

C.B. and S.R. conceived and designed the study. S.R., E.F., M.C., P.O. and M.I.P. contributed reagents/materials/analysis tools for gene expression and DNA methylation studies and parameter analysis. L.R. handled the animals. M.I.P. and J.J.A-M analyzed the data. C.B. wrote the paper. None of the authors have any conflicts of interest to report.

\section{References}

1. Nichols M, Townsend N, Scarborough P, Rayner M. Cardiovascular disease in Europe 2014: epidemiological update. Eur Heart J 2014; 35:2950-9.

2. Barker DJ, Clark PM. Fetal undernutrition and disease in later life. Rev Reprod 1997; 2(2):105-12. 
3. Godfrey KM, Barker DJ. Fetal programming and adult health. Public Health Nutr 2001; 4(2B):611-24.

4. Kereliuk SM, Brawerman GM, Dolinsky VW. Maternal macronutrient consumption and the developmental origins of metabolic disease in the offspring. Int J Mol Sci 2017; 18(7):E1451.

5. Wadhwa PD, Buss C, Entringer S, Swanson JM. Developmental Origins of Health and Disease: brief history of the approach and current focus on epigenetic mechanisms. Semin Reprod Med 2009; 27(5):358-68.

6. Beck B, Richy S, Archer ZA, Mercer JG. Ingestion of carbohydrate-rich supplements during gestation programs insulin and leptin resistance but not body weight gain in adult rat offspring. Front Physiol 2012; 3:224.

7. Sedova L, Seda O, Kazdova L, Chylikova B, Hamet P, Tremblay J, et al. Sucrose feeding during pregnancy and lactation elicits distinct metabolic response in offspring of an inbred genetic model of metabolic syndrome. Am J Physiol Endocrinol Metab 2007; 292:E1318-24.

8. Wu G, Bazer FW, Cudd TA, Meininger CJ, Spencer TE. Maternal nutrition and fetal development. J Nutr 2004; 134(9):2169-72.

9. Johnson RJ, Segal MS, Sautin Y, Nakagawa T, Feig DI, Kang DH, et al. Potential role of sugar (fructose) in the epidemic of hypertension, obesity and the metabolic syndrome, diabetes, kidney disease, and cardiovascular disease. Am J Clin Nutr 2007; 86:899-906.

10. Stanhope KL, Schwarz JM, Havel PJ. Adverse metabolic effects of dietary fructose: results from the recent epidemiological, clinical, and mechanistic studies. Curr Opin Lipidol 2013; 24(3):198-206.

11. Wong SK, Chin K-Y, Suhaimi FH, Fairus A, Ima-Nirwana S. Animal models of metabolic syndrome: a review. Nutr Metab 2016; 13:65.

12. Aydin S, Aksoy A, Aydin S, Kalayci M, Yilmaz M, Kuloglu T, et al. Today's and yesterday's of pathophysiology: biochemistry of metabolic syndrome and animal models. Nutrition 2014; 30(1):1-9.

13. Roglans N, Vilà L, Farré M, Alegret M, Sánchez RM, Vázquez-Carrera $M$, et al. Impairment of hepatic Stat-3 activation and reduction of PPAR alpha activity in fructosefed rats. Hepatology 2007; 45(3):778-88.

14. Roglans N, Sanguino E, Peris C, Alegret M, Vázquez-Carrera M, Adzet T, et al. Atorvastatin treatment induced peroxisome proliferator-activated receptor alpha expression and decreased plasma nonesterified fatty acids and liver triglyceride in fructose-fed rats. J Pharmacol Exp Ther 2002; 302(1):232-9.

15. Rodrigo S, Rodríguez L, Otero P, Panadero MI, García A, Barbas C, et al. Fructose during pregnancy provokes fetal oxidative stress: The key role of the placental heme oxygenase-1. Mol Nutr Food Res 2016; 60(12):2700-11.

16. Rodríguez L, Panadero MI, Roglans N, Otero P, Álvarez-Millán JJ, Laguna JC, et al. Fructose during pregnancy affects maternal and fetal leptin signaling. J Nutr Biochem $2013 ; 24: 1709-16$. 
17. Rodríguez L, Panadero MI, Roglans N, Otero P, Rodrigo S, Alvarez-Millán JJ, et al. Fructose only in pregnancy provokes hyperinsulinemia, hypoadiponectinemia and impaired insulin signaling in adult male, but not female, progeny. Eur J Nutr 2016; 55(2):665-74.

18. Rodríguez L, Panadero MI, Rodrigo S, Roglans N, Otero P, Alvarez-Millán JJ, et al. Liquid fructose in pregnancy exacerbates fructose-induced dyslipidemia in adult female offspring. J Nutr Biochem 2016; 32:115-22.

19. Burdge GC, Hanson MA, Slater-Jefferies JL, Lillycrop KA. Epigenetic regulation of transcription: a mechanism for inducing variations in phenotype (fetal programming) by differences in nutrition during early life? Br J Nutr 2007; 97:1036-46.

20. Seki Y, Williams L, Vuguin PM, Charron MJ. Minireview: epigenetic programming of diabetes and obesity: animal models. Endocrinology 2012; 153(3):1031-8.

21. Lillycrop KA, Phillips ES, Jackson AA, Hanson MA, Burdge GC. Dietary protein restriction of pregnant rats induces and folic acid supplementation prevents epigenetic modification of hepatic gene expression in the offspring. J Nutr 2005; 135:1382-6.

22. Laker RC, Lillard TS, Okutsu M, Zhang M, Hoehn KL, Connelly JJ, et al. Exercise prevents maternal high-fat diet-induced hypermethylation of the Pgc-1a gene and agedependent metabolic dysfunction in the offspring. Diabetes 2014; 63(5):1605-11.

23. Yu H-L, Dong S, Gao L-F, Li L, Xi Y-D, Ma W-W et al. Global DNA methylation was changed by a maternal high-lipid, high-energy diet during gestation and lactation in male adult mice liver. Br J Nutr 2015; 113(7):1032-9.

24. Van Straten EM, Bloks VW, Huijkman NC, Baller JF, van Meer H, Lutjohann D, et al. The liver X-receptor gene promoter is hypermethylated in a mouse model of prenatal protein restriction. Am J Physiol Regul Integr Comp Physiol 2010; 298(2):R275-82.

25. Del Bas JM, Crescenti A, Arola-Arnal A, Oms-Oliu G, Arola L, Caimari A. Intake of grape procyanidins during gestation and lactation impairs reverse cholesterol transport and increases atherogenic risk indexes in adult offspring. J Nutr Biochem 2015; 26(12):1670-7.

26. Ohashi K, Munetsuna E, Yamada H, Ando Y, Yamazaki M, Taromaru N, et al. High fructose consumption induces DNA methylation at PPAR $\alpha$ and CPT1A promoter regions in the rat liver. Biochem Biophys Res Commun 2015; 468(1):185-9.

27. Yamazaki M, Yamada H, Munetsuna E, Ishikawa H, Mizuno G, Mukuda T, et al. Excess maternal fructose consumption impairs hippocampal function in offspring via epigenetic modification of BDNF promoter. FASEB J 2018; 32(5):2549-62.

28. De Koning, L, Malik VS, Kellogg MD, Rimm EB, Willett WC, Hu FB. Sweetened beverage consumption, incident coronary heart disease, and biomarkers of risk in men. Circulation 2012; 125(14):1735-41.

29. Gugliucci, A. Maternal fructose consumption can affect offspring metabolic outcomes. J Physiol 2017; 595(13):4133-4. 
30. Saad AF, Dickerson J, Kechichian TB, Yin H, Gamble P, Salazar A, et al. Highfructose diet in pregnancy leads to fetal programming of hypertension, insulin resistance, and obesity in adult offspring. Am J Obstet Gynecol 2016; 215(378):e1-6.

31. Ching RHH, Yeung LOY, Tse IMY, Sit W-H, Li ETS. Supplementation of bitter melon to rats fed a high-fructose diet during gestation and lactation ameliorates fructoseinduced dyslipidemia and hepatic oxidative stress in male offspring. J Nutr 2011; 141(9):1664-72.

32. Alzamendi A, Castrogiovanni D, Gaillard RC, Spinedi E, Giovambattista A. Increased male offspring's risk of metabolic-neuroendocrine dysfunction and overweight after fructose-rich diet intake by the lactating mother. Endocrinology 2010; 151:4214-23.

33. Folch J, Lees M, Sloane Stanley GH. A simple method for the isolation and purification of total lipids from animal tissues. J Biol Chem 1957; 226(1):497-509.

34. Rozen S, Skaletsky H. Primer3 on the WWW for general users and for biologist programmers. Methods Mol Biol 2000; 132:365-86.

35. Pfaffl MW. A new mathematical model for relative quantification in real-time RTPCR. Nucleic Acids Res 2001; 29(9):e45.

36. Oakes CC, La Salle S, Robaire B, Trasler JM. Evaluation of a quantitative DNA methylation analysis technique using methylation-sensitive/dependent restriction enzymes and real-time PCR. Epigenetics 2006; 1:146-52.

37. Li LC, Dahiya R. MethPrimer: Designing primers for methylation PCRs. Bioinformatics (Oxford, England) 2002; 18(11):1427-31.

38. Otero P, de la Cuesta M, Fauste E, Rodrigo S, Panadero MI, Álvarez-Millán JJ, et al. Fetal programming and nutrigenomics: Different response of female progeny versus male progeny in cholesterolemia to maternal intake of fructose. Abstract from the $85^{\text {th }}$ European Atherosclerosis Society (EAS) Congress. Prague (Czech Republic). Atherosclerosis 2017; 263:e170.

39. Calkin AC, Tontonoz P. Transcriptional integration of metabolism by the nuclear sterol-activated receptors LXR and FXR. Nat Rev Mol Cell Biol 2012; 13(4):213-24.

40. Downing LE, Edgar D, Ellison PA, Ricketts M-L. Mechanistic insight into nuclear receptor-mediated regulation of bile acid metabolism and lipid homeostasis by grape seed procyanidin extract (GSPE). Cell Biochem Funct 2017; 35:12-32.

41. Ma Z, Deng C, Hu W, Zhou J, Fan C, Di S, et al. Liver X Receptors and their agonists: targeting for cholesterol homeostasis and cardiovascular diseases. Curr Issues Mol Biol 2017; 22:41-64.

42. Kir S, Beddow SA, Samuel VT, Miller P, Previs SF, Suino-Powell K, et al. FGF19 as a postprandial, insulin-independent activator of hepatic protein and glycogen synthesis. Science 2011; 331:1621-4.

43. Strable MS, Ntambi JM. Genetic control of de novo lipogenesis: role in diet-induced obesity. Crit Rev Biochem Mol Biol 2010; 45(3):199-214. 
44. Renga B, Francisci D, Carino A, Marchiano S, Cipriani S, Chiara Monti M, et al. The HIV matrix protein p17 induces hepatic lipid accumulation via modulation of nuclear receptor transcriptoma. Sci Rep 2015; 5:15403.

45. Martínez D, Pentinat T, Ribó S, Daviaud C, Bloks VW, Cebriá J. In utero undernutrition in male mice programs liver lipid metabolism in the second-generation offspring involving altered Lxra DNA methylation. Cell Metab 2014; 19:941-51.

46. Münzberg H, Björnholm M, Bates SH, Myers Jr MG. Leptin receptor action and mechanisms of leptin resistance. Cell Mol Life Sci 2005; 62:642-52.

47. Lillycrop KA, Phillips ES, Torrens C, Hanson MA, Jackson AA, Burdge GC. Feeding pregnant rats a protein-restricted diet persistently alters the methylation of specific cytosines in the hepatic PPAR $\alpha$ promoter of the offspring. Br J Nutr 2008; 100:27882.

48. Jacob RA, Gretz DM, Taylor PC, James SJ, Pogribny IP, Miller BJ, et al. Moderate folate depletion increases plasma homocysteine and decreases lymphocyte DNA methylation in postmenopausal women. J Nutr 1998; 128:1204-12.

49. Castaño E, Caviedes L, Hirsch S, Llanos M, Iñiguez G, Ronco AM. Folate transporters in placentas from preterm newborns and their relation to cord blood folate and vitamin B12 levels. PLoS ONE 2017; 12(1):e0170389.

50. Partearroyo T, Samaniego-Vaesken ML, Ruiz E, Aranceta-Batrina J, Gil A, GonzálezGross M, et al. Dietary sources and intakes of folates and vitamin B12 in the Spanish population: findings from the ANIBES study. PLoS ONE 2017; 12(12): e0189230.

51. Steinberg SE, Campbell CL, Hillman RS. Kinetics of the normal folate enterohepatic cycle. J Clin Invest 1979; 64:83-8.

52. Said HM, Hollander D, Strum WB. Inhibitory effect of unconjugated bile acids on the intestinal transport of 5-methyltetrahydrofolate in rat jejunum in vitro. Gut 1984; 25:1376-9.

53. West RJ, Lloyd JK. The effect of cholestyramine on intestinal absorption. Gut 1975; 16:93-8.

54. Spruss A, Bergheim I. Dietary fructose and intestinal barrier: potential risk factor in the pathogenesis of nonalcoholic fatty liver disease. J Nutr Biochem 2009; 20:657-62.

55. Mardinoglu A, Wu H, Bjornson E, Backhed F, Taskinen M-R, Boren J. An integrated understanding of the rapid metabolic benefits of a carbohydrate-restricted diet on hepatic steatosis in humans. Cell Metab 2018; 27:1-13.

56. Christensen KE, Mikael LG, Leung K-Y, Lévesque N, Deng L, Wu Q, et al. High folic acid consumption leads to pseudo-MTFHR deficiency, altered lipid metabolism, and liver injury in mice. Am J Clin Nutr 2015; 101:646-58.

57. Yuan, X., Tsujimoto, K., Hashimoto, K., Kawahori, K., Hanzawa, N., Hamaguchi, M., et al. Epigenetic modulation of Fgf21 in the perinatal mouse liver ameliorates dietinduced obesity in adulthood. Nat Commun 2018; 9:636. 
58. Vickers $\mathrm{MH}$, Clayton ZE, Yap C, Sloboda DM. Maternal fructose intake during pregnancy and lactation alters placental growth and leads to sex-specific changes in fetal and neonatal endocrine function. Endocrinology 2011; 152(4):1378-87.

59. Mauvais-Jarvis F. Sex differences in metabolic homeostasis, diabetes, and obesity. Biol Sex Differ 2015; 6:14.

60. Galipeau D, Verma S, McNeill JH. Female rats are protected against fructose-induced changes in metabolism and blood pressure. Am J Physiol Heart Circ Physiol 2002; 283:H2478-84.

61. Kautzky-Willer A, Harreiter K, Pacini G. Sex and gender differences in risk, pathophysiology and complications of Type 2 Diabetes Mellitus. Endocr Rev 2016; 37(3):278-316.

62. Van der Veen JN, Havinga R, Bloks VW, Groen AK, Kuipers F. Cholesterol feeding strongly reduces hepatic VLDL-triglyceride production in mice lacking the liver $\mathrm{X}$ receptor $\alpha$. J Lipid Res 2007; 48:337-47.

63. Tokita Y, Hirayama Y, Sekikawa A, Kotake H, Toyota T, Miyazawa T, et al. Fructose ingestion enhances atherosclerosis and deposition of advanced glycated end-products in cholesterol-fed rabbits. Atheroscler Thromb 2005; 12(5):260-7.

64. Clayton ZE, Vickers MH, Bernal A, Yap C, Sloboda DM. Early life exposure to fructose alters maternal, fetal and neonatal hepatic gene expression and leads to sexdependent changes in lipid metabolism in rat offspring. PLoS ONE 2015; 10(11): e0141962.

65. Tobi EW, Slieker RC, Luijk R, Dekkers KF, Stein AD, Xu KM, et al. DNA methylation as a mediator of the association between prenatal adversity and risk factors for metabolic disease in adulthood. Sci Adv 2018; 4(1):eaao4364. 


\section{Legends}

Fig. 1. Structure of the rat $\mathrm{LXR} \alpha$ gene promoter. Postulated $\mathrm{CpG}$ islands are in bold. Forward (F) and reverse (R) primers used for PCR amplification are underlined. Transcription factor binding sites for transcription factors such as PPARy and STAT3, according to Champion ChiP Transcription Factor Search Portal (SABiosciences database, DECODE, Qiagen), are also indicated. TSS for LXR $\alpha$ gene transcripts are underlined (from National Center for Biotechnology Information, U.S. National Library of Medicine, MD, USA). LXR $\alpha$, liver Xreceptor alpha; $\mathrm{CpG}$ islands, $\mathrm{CG}$-dinucleotide-rich regions in the promoter of a gene; PPAR $\gamma$, Peroxisome proliferator-activated receptor gamma; STAT3, Signal transducer and activator of transcription-3; TSS: Transcription start site; TIS: Translation initiation site.

Fig. 2. Fructose in pregnancy affects the hepatic RCT mRNA gene expression in adult progeny in a gender-dependent manner. Male and female (A) relative hepatic levels of specific mRNA for Scavenger Receptor class B, member 1 (SRB-1) of 261-day-old progeny from control (empty bar), fructose-fed (black bar) and glucose-fed (grey bar) pregnant rats. Male and female (B) relative hepatic levels of specific mRNA for ATP-binding cassette G5 (ABCG5) of 261-day-old progeny from control (empty bar), fructose-fed (black bar) and glucose-fed (grey bar) pregnant rats. Male and female $(\mathrm{C})$ relative hepatic values of specific mRNA for cholesterol 7-alpha hydroxylase (CYP7A1) of 261-day-old progeny from control (empty bar), fructose- (black bar) and glucose-fed (grey bar) pregnant rats. Relative target gene mRNA levels were measured by Real Time PCR, as explained in Materials and Methods, and normalized to Rps29 levels and expressed in arbitrary units (a.u.). Each bar represents the mean \pm SE from 5-6 litters analyzed by two-way ANOVA, followed by Bonferroni's post hoc test. The significant effects of gender (G), diet (D) and their interaction (GxD) were tested by two-way ANOVA and $\mathrm{p}$ value and $\eta 2$ (i.e. the proportion of the total variance that is attributed to the corresponding effect) are shown. Post hoc analysis is indicated by $* \mathrm{p}<0.05$ between groups; and $\S \mathrm{p}<0.05$ females versus males. RCT: Reverse cholesterol transport.

Fig. 3. Fructose in gestation influences the hepatic cholesterol biosynthesis and uptake mRNA gene expression in adult progeny in a gender-dependent manner. Male and female (A) relative hepatic levels of specific mRNA for LDL receptor (LDLR) of 261-day-old progeny from control (empty bar), fructose-fed (black bar) and glucose-fed (grey bar) pregnant rats. Male and female 
(B) relative hepatic levels of specific mRNA for 3-hydroxy-3-methylglutaryl-CoA reductase (HMG-CoA reductase) of 261-day-old progeny from control (empty bar), fructose-fed (black bar) and glucose-fed (grey bar) pregnant rats. Male and female (C) relative hepatic values of specific mRNA for Sterol Response Element Binding Protein 2 (SREBP2) of 261-day-old progeny from control (empty bar), fructose-fed (black bar) and glucose-fed (grey bar) pregnant rats. Relative target gene mRNA levels were measured by Real Time PCR, as explained in Materials and Methods, and normalized to Rps29 levels and expressed in arbitrary units (a.u.). Each bar represents the mean \pm SE from 5-6 litters analyzed by two-way ANOVA, followed by Bonferroni's post hoc analysis. The significant effects of gender (G), diet (D) and their interaction $(\mathrm{GxD})$ were tested by two-way ANOVA and $\mathrm{p}$ value and $\eta 2$ (i.e. the proportion of the total variance that is attributed to the corresponding effect) are shown. Post hoc analysis is indicated by $* p<0.05$ between groups; and $\S p<0.05$ females versus males.

Fig. 4. Fructose in gestation affects promoter methylation and mRNA gene expression of transcription factor LXR $\alpha$ in adult progeny in a gender-dependent manner. Male and female (A) percentage of promoter methylation of LXR $\alpha$ gene of 261-day-old progeny from control (empty bar), fructose-fed (black bar) and glucose-fed (grey bar) pregnant rats. Male and female (B) relative hepatic levels of specific mRNA for Liver X receptor alpha (LXR $\alpha)$ of 261-day-old progeny from control (empty bar), fructose-fed (black bar) and glucose-fed (grey bar) pregnant rats. Relative target gene mRNA levels were measured by Real Time PCR, as explained in Materials and Methods, and normalized to Rps29 levels and expressed in arbitrary units (a.u.). The LXR $\alpha$ region studied to measure promoter methylation is indicated in detail in Figure 1. Shifts in the $\mathrm{Ct}$ values $(\Delta \mathrm{Ct})$ of the enzyme-digested samples were expressed relative to the sham-digested samples and used to calculate the percentage of methylation at the $\mathrm{CpG}$ sites within the amplified region. The percentage of methylation was obtained by using the formula: $\%=100\left(1-\mathrm{e}^{-0.7(\Delta \mathrm{Ct})}\right)$. Each bar represents the mean $\pm \mathrm{SE}$ from 56 litters analyzed by two-way ANOVA, followed by Bonferroni's post hoc test. The significant effects of gender $(\mathrm{G})$, diet $(\mathrm{D})$ and their interaction $(\mathrm{GxD})$ were tested by two-way ANOVA and $\mathrm{p}$ value and $\eta 2$ (i.e. the proportion of the total variance that is attributed to the corresponding effect) are shown. Post hoc analysis is indicated by * $\mathrm{p}<0.05$ between groups; and $\S \mathrm{p}<0.05$ females versus males. 
Fig. 5. Fructose in pregnancy modifies plasma folic acid levels in adult progeny in a genderdependent manner. Male and female plasma folic acid values of 261-day-old progeny from control (empty bar), fructose-fed (black bar) and glucose-fed (grey bar) pregnant rats. Each bar represents the mean \pm SE from 5-6 litters analyzed by two-way ANOVA, followed by Bonferroni's post hoc test. The significant effects of gender (G), diet (D) and their interaction (GxD) were tested by two-way ANOVA and $p$ value and $\eta 2$ (i.e. the proportion of the total variance that is attributed to the corresponding effect) are shown. Post hoc analysis is indicated by $* \mathrm{p}<0.05$ between groups; and $\S \mathrm{p}<0.05$ females versus males. 
-1454 GCAATTCCGGGCCGTGCCGGGACCTTTGCTCCGCGAGGTGTCTATGGGAGGAGGGgGGAGGGAA PPAR $\gamma$

-1390 CGCTGACTCTGGAGGCTGCTGGGATTAGGGTGGGGGTGACTGAGAAAGCAGTCCTTCTGTAAGA

-1326 GCAAAGAGCCTCCAGGGTGAGGAGAGGAAGGAGAGAGATGGAACTAGGCCGGTCTGCGGGGAAA F Primer STAT3

-1262 CGCGACAGTCTTGGTAGAGGGTAGGGGA_CAGGATGGCGCCGGCTAAGAGAGTGGCTGCCTGGGG

-1198 AgGAGTTAGTCTGGTGGGGAAGCTATCTCGTGGGCGGGAGCCTAAAGGGGC ${ }^{-1147}[\ldots]^{-22}$ AGGAC R Primer

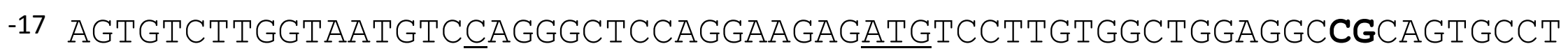
TIS

48 GATGtTTCTCCTGGTAAgCTgtTtTATtCAACCCCTTCTCCCCAGAGCCCAGGCCTCTGGCTCC Splicing site 5'

112 TTTCCT $118[. . .]^{826}$ TGGATAGGACCTGAACCCATACCCACTCCCCTGTGCTTCTCTTGGGCTCAG

878 ACTCTGCAACGGAGTTGTGGAAGACAGAACCTCAAGATGCAGGAGACCAGGGAGGCAACACTTG Splicing site 3'

942 CATCCTtAgGGAgGAAGCCAGGATGCCCCAAtCAACTGGGGGTGCTTTAAGGATAGGGTTG... 

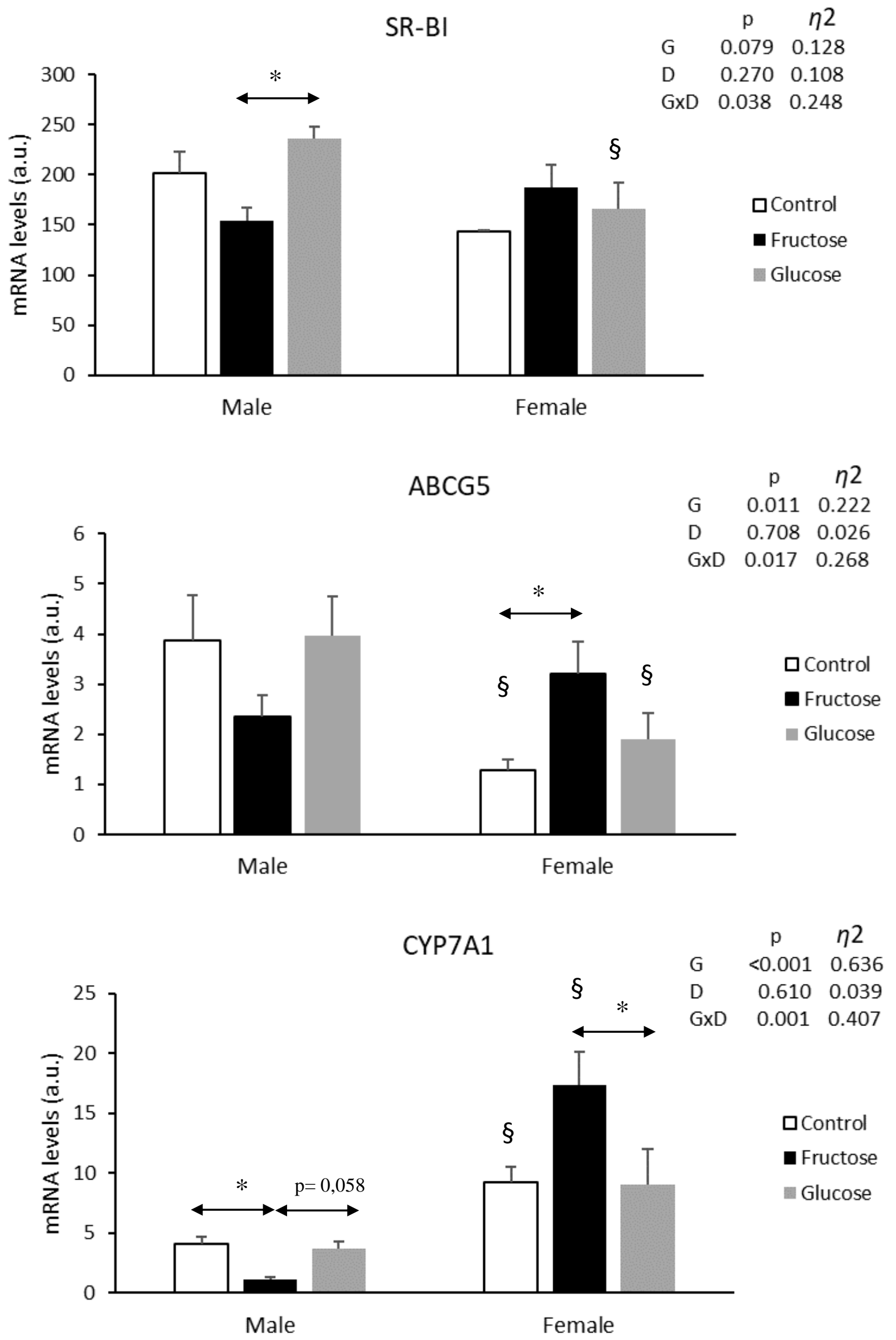

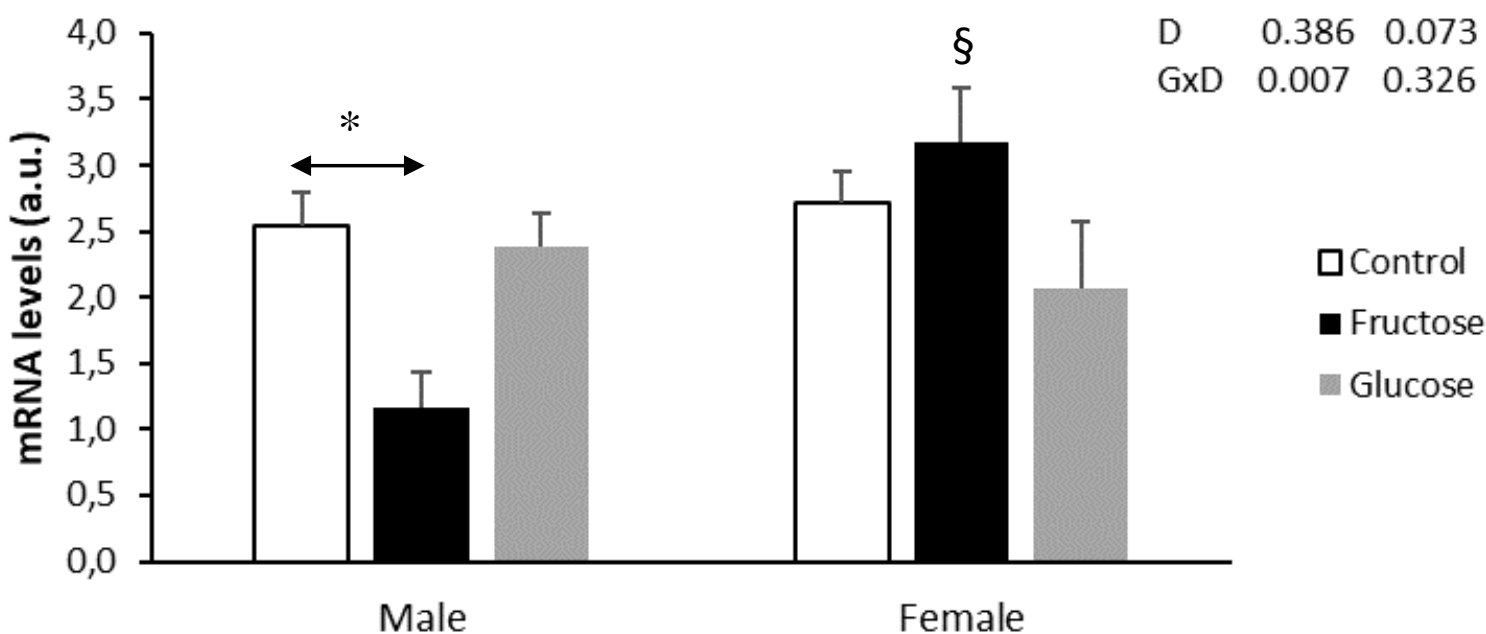

口Control

- Fructose

alucose
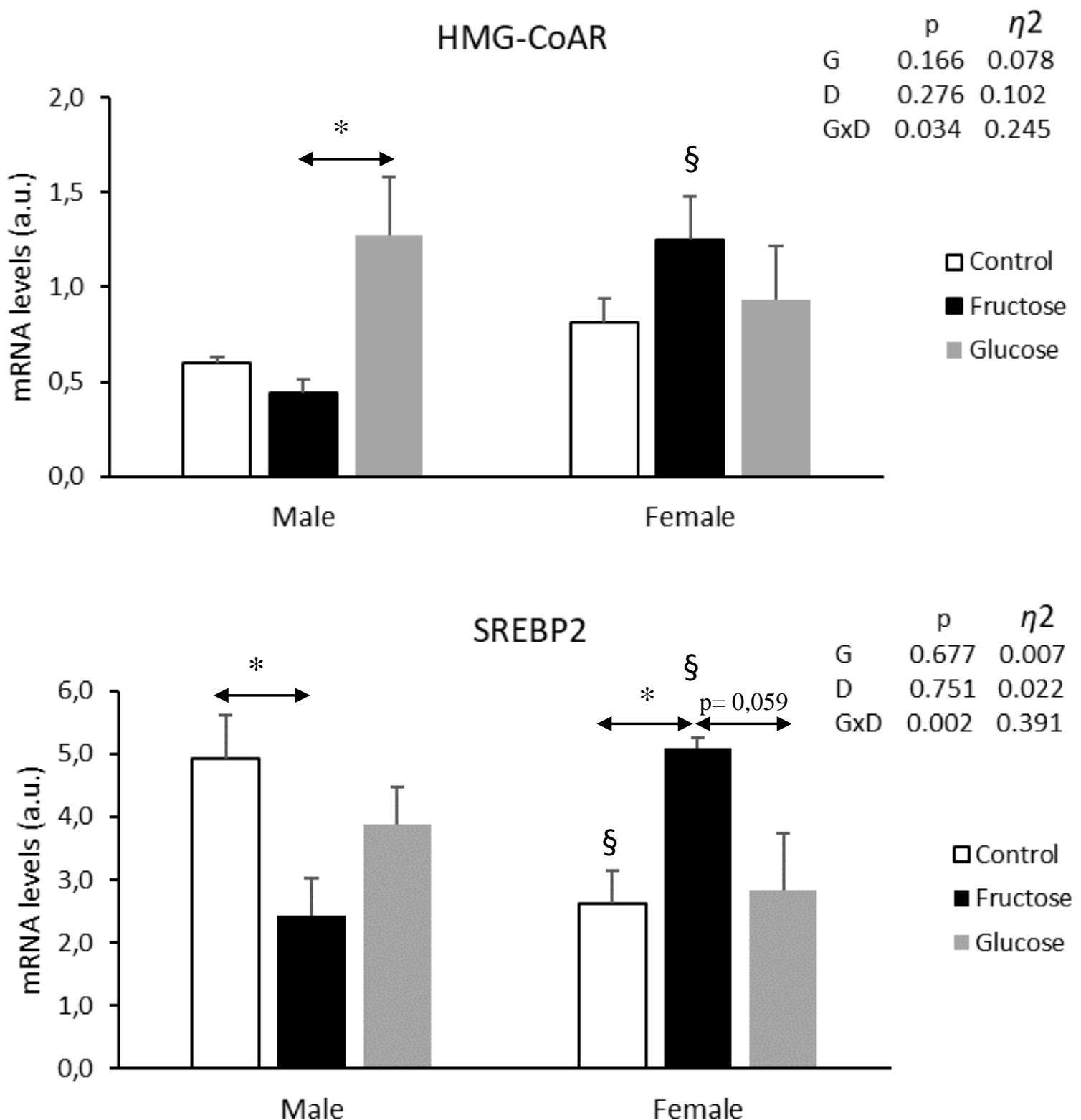

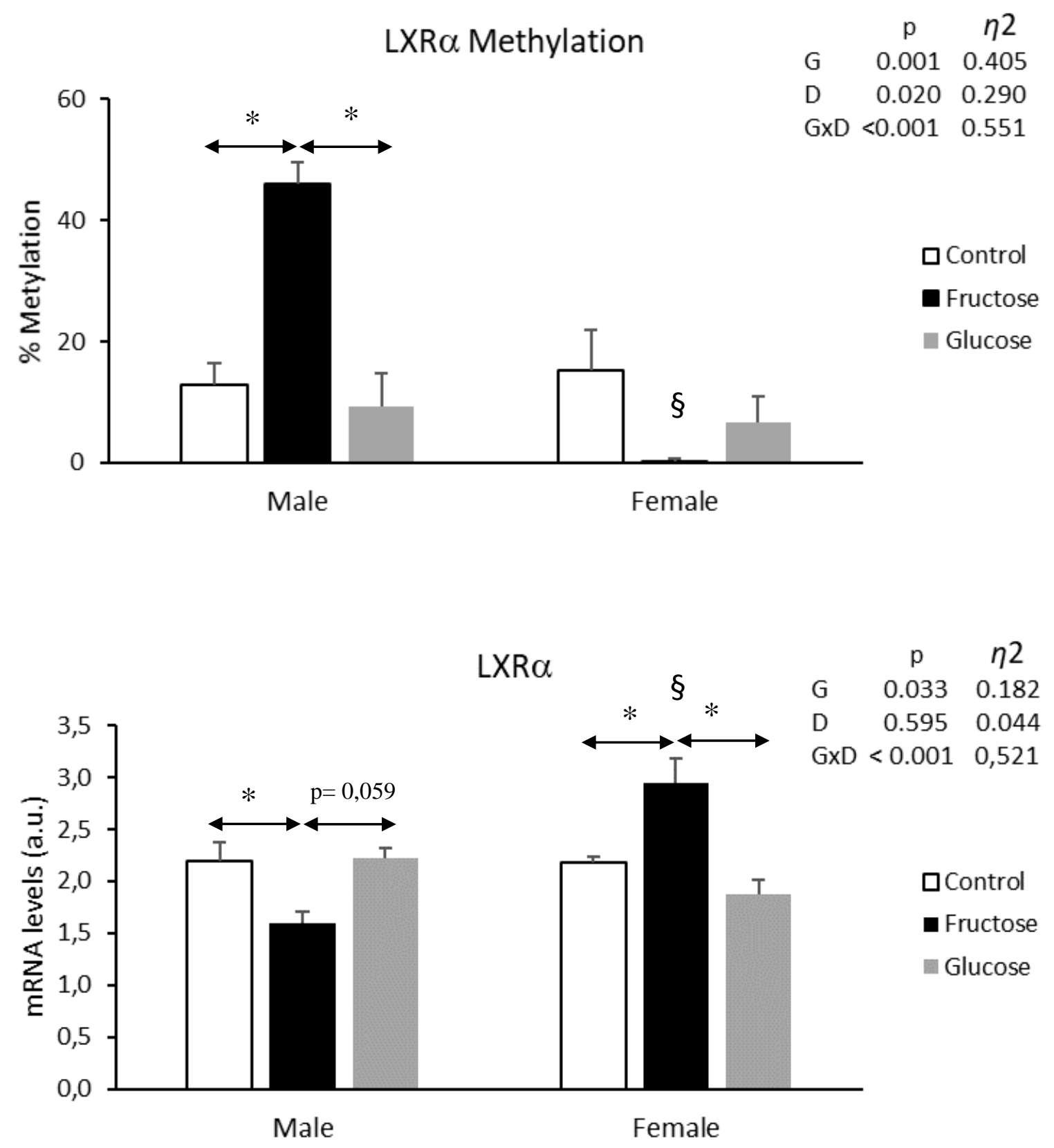


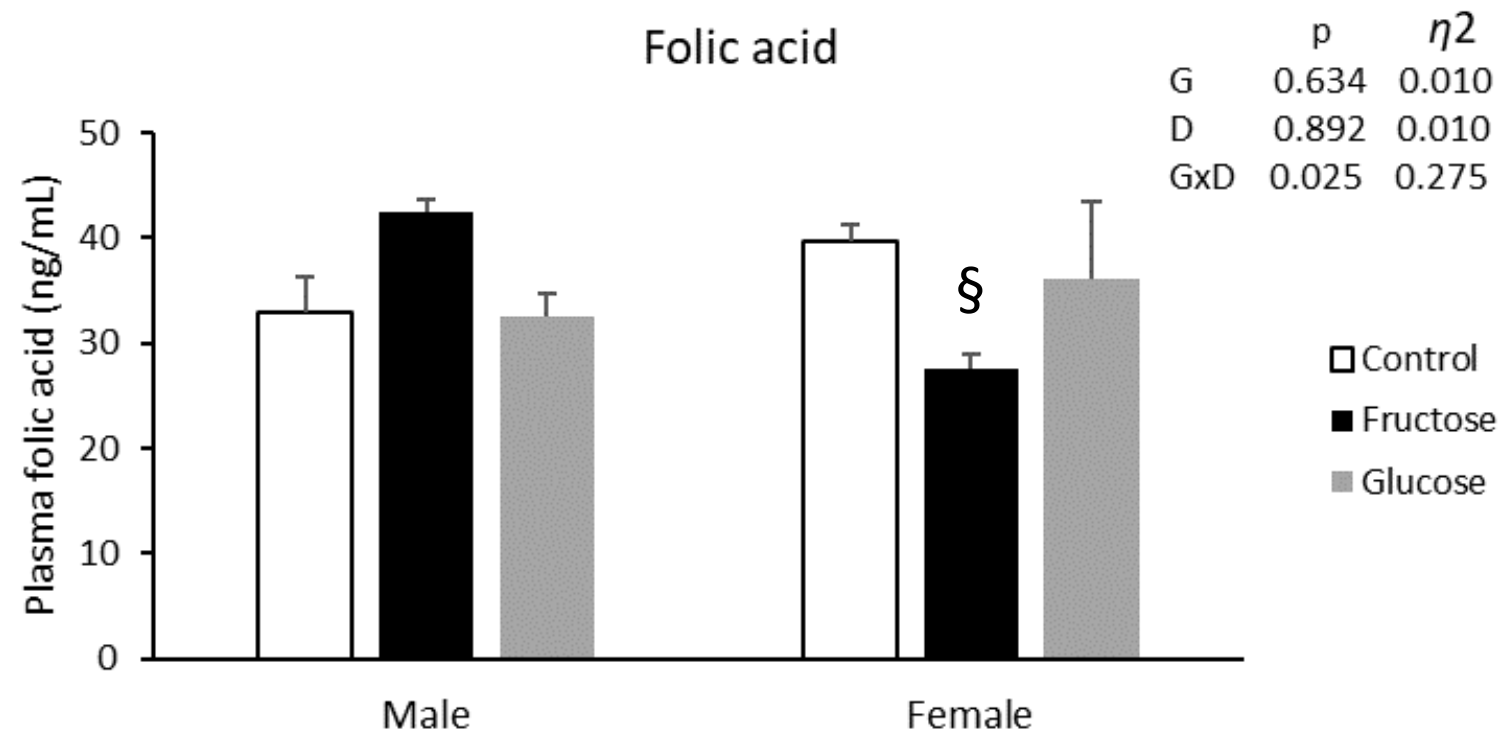




\section{Table 1}

Plasma and liver analytes in male and female adult progeny from fructose-fed or glucose-supplemented and control mothers

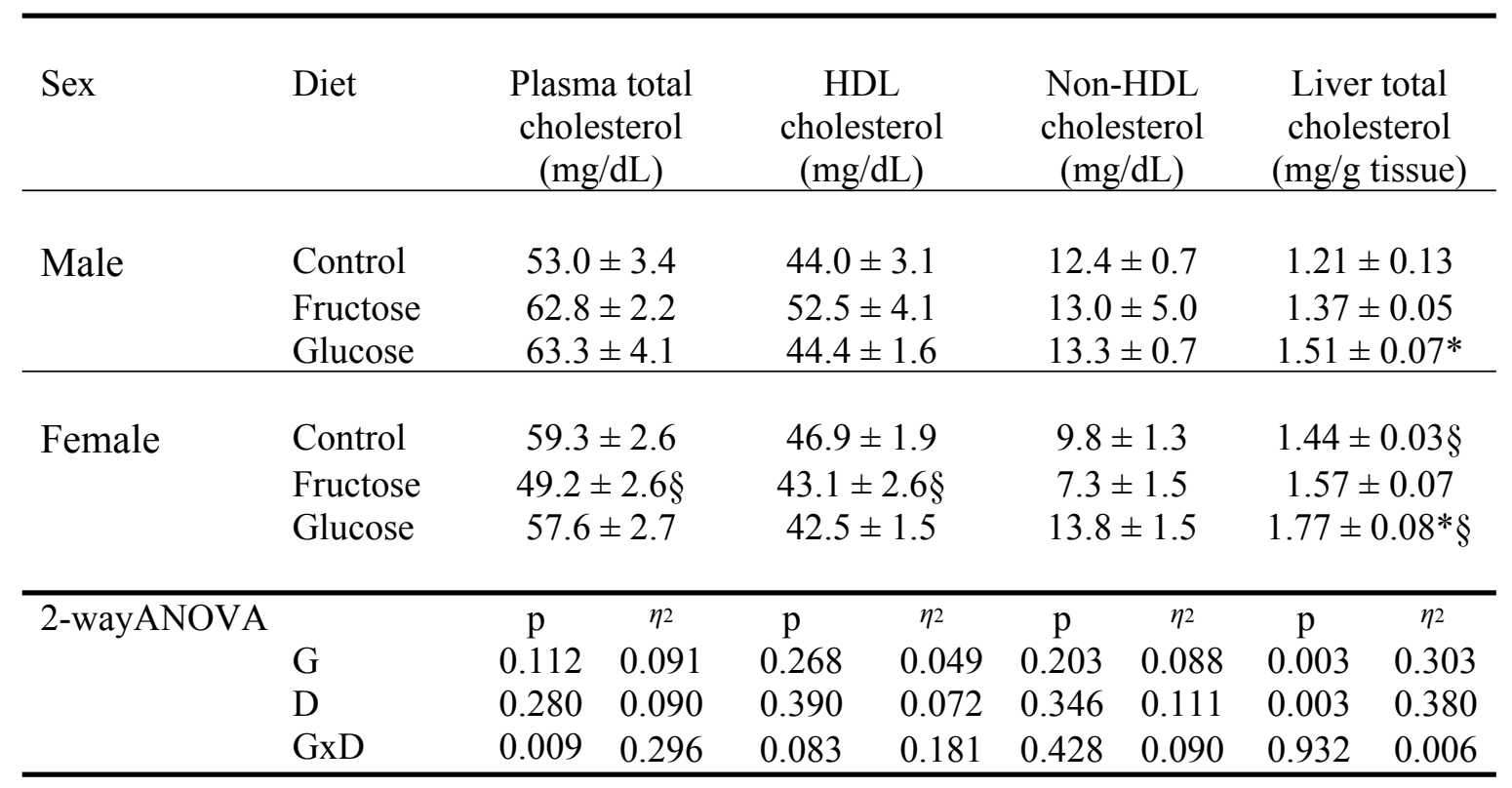

Data are mean \pm SE from 5-6 litters analyzed by two-way ANOVA, followed by Bonferroni's post hoc test. The significant effects of gender (G), diet (D) and their interaction $(\mathrm{GxD})$ were tested by two-way ANOVA and $\mathrm{p}$ value and $\eta 2$ (i.e. the proportion of the total variance that is attributed to the corresponding effect) are shown. Post hoc analysis is indicated by $* \mathrm{p}<0.05$ versus control group; and $\S \mathrm{p}<0.05$ females versus males. 


\section{Table 2}

Plasma analytes and liver (mRNA) gene expression in male and female adult progeny from fructose-fed or glucose-supplemented and control mothers

\begin{tabular}{|c|c|c|c|c|c|c|c|c|c|c|c|}
\hline \multirow[t]{2}{*}{ Gender } & \multirow[t]{2}{*}{ Diet } & \multirow{2}{*}{\multicolumn{2}{|c|}{$\begin{array}{l}\text { Plasma bile } \\
\text { acids }(\mu \mathrm{M})\end{array}$}} & \multicolumn{8}{|c|}{ Liver mRNA expression } \\
\hline & & & & Bsep & (a.u.) & \multicolumn{2}{|c|}{ NTCP (a.u.) } & \multicolumn{2}{|c|}{ Shp (a.u.) } & \multicolumn{2}{|c|}{ LRH1 (a.u.) } \\
\hline Male & $\begin{array}{l}\text { Control } \\
\text { Fructose } \\
\text { Glucose }\end{array}$ & $\begin{array}{r}9.0= \\
16.4 \\
10.4\end{array}$ & $\begin{array}{l}0.8 \\
3.6 \\
2.8\end{array}$ & $\begin{array}{l}2.74 \\
2.41 \\
2.70\end{array}$ & $\begin{array}{l}=0.24 \\
=0.10 \\
=0.12\end{array}$ & $\begin{array}{l}3.58= \\
3.60= \\
4.44=\end{array}$ & $\begin{array}{l}0.25 \\
0.25 \\
0.18\end{array}$ & $\begin{array}{l}3.28 \\
3.95 \\
4.88\end{array}$ & $\begin{array}{l}0.17 \\
0.40 \\
1.61\end{array}$ & $\begin{array}{c}11.0 \\
9.4= \\
13.0\end{array}$ & $\begin{array}{l}=1.1 \\
1.8 \\
=0.8\end{array}$ \\
\hline Female & $\begin{array}{l}\text { Control } \\
\text { Fructose } \\
\text { Glucose }\end{array}$ & \multicolumn{2}{|c|}{$\begin{array}{c}12.7 \pm 2.4 \# \\
58.8 \pm 16.0 \S\end{array}$} & \multicolumn{2}{|c|}{$\begin{array}{l}2.78 \pm 0.23 \\
2.38 \pm 0.26\end{array}$} & \multicolumn{2}{|c|}{$\begin{array}{c}3.96 \pm 0.47 \\
3.15 \pm 0.74 \S\end{array}$} & \multicolumn{2}{|c|}{$\begin{array}{l}3.92 \pm 0.64 \\
6.84 \pm 2.61\end{array}$} & \multicolumn{2}{|c|}{$\begin{array}{c}13.7 \pm 1.0 \S \\
9.5 \pm 2.0\end{array}$} \\
\hline 2-wayA & $\begin{array}{l}\text { JOVA } \\
\text { G } \\
\text { D } \\
\text { GxD }\end{array}$ & $\begin{array}{c}\mathrm{p} \\
0.001 \\
0.143 \\
0.002\end{array}$ & $\begin{array}{c}\eta^{2} \\
0.363 \\
0.139 \\
0.371\end{array}$ & $\begin{array}{c}\mathrm{p} \\
0.900 \\
0.779 \\
0.251\end{array}$ & $\begin{array}{c}\eta^{2} \\
0.001 \\
0.020 \\
0.105\end{array}$ & $\begin{array}{c}\mathrm{p} \\
0.314 \\
0.741 \\
0.179\end{array}$ & $\begin{array}{c}\eta^{2} \\
0.042 \\
0.025 \\
0.134\end{array}$ & $\begin{array}{c}\mathrm{p} \\
0.335 \\
0.275 \\
0.760\end{array}$ & $\begin{array}{c}\eta^{2} \\
0.037 \\
0.098 \\
0.022\end{array}$ & $\begin{array}{c}\mathrm{p} \\
0.697 \\
0.981 \\
0.031\end{array}$ & $\begin{array}{c}\eta^{2} \\
0.006 \\
0.001 \\
0.227\end{array}$ \\
\hline
\end{tabular}

Relative target gene mRNA levels were measured by Real Time PCR, as explained in Materials and Methods, normalized to Rps29 levels and expressed in arbitrary units (a.u.). Data are mean \pm SE from 5-6 litters analyzed by two-way ANOVA, followed by Bonferroni's post hoc test. The significant effects of gender (G), diet (D) and their interaction (GxD) were tested by two-way ANOVA and $p$ value and $\eta 2$ (i.e. the proportion of the total variance that is attributed to the corresponding effect) are shown. Post hoc analysis is indicated by $* \mathrm{p}<0.05$ versus control group; $\# \mathrm{p}<0.05$ fructose versus glucose group; and $\S \mathrm{p}<0.05$ females versus males. 


\section{Table 3}

Liver (mRNA) gene expression in male and female adult progeny from fructose-fed or glucose-supplemented and control

\begin{tabular}{|c|c|c|c|c|c|c|c|c|c|c|c|c|c|c|c|c|c|c|c|}
\hline Gender & Diet & \multicolumn{2}{|c|}{ SREBP1c } & \multicolumn{2}{|l|}{$\mathrm{ACC}$} & \multicolumn{2}{|l|}{ FAS } & \multicolumn{2}{|l|}{ SCD1 } & \multicolumn{2}{|c|}{ ABCA1 } & \multicolumn{2}{|c|}{ PPAR $\alpha$} & \multicolumn{2}{|l|}{ Dnmt1 } & \multicolumn{2}{|c|}{ Dnmt3a } & \multicolumn{2}{|c|}{ Dnmt3b } \\
\hline \multirow[t]{3}{*}{ Male } & Control & \multirow{3}{*}{\multicolumn{2}{|c|}{$\begin{array}{l}6.70 \pm 0.56 \\
1.71 \pm 0.46^{* \#} \\
3.83 \pm 0.34^{*} \\
\end{array}$}} & \multirow{3}{*}{\multicolumn{2}{|c|}{$\begin{array}{l}7.14 \pm 1.20 \\
3.43 \pm 0.84^{*} \\
4.89 \pm 0.43\end{array}$}} & \multirow{3}{*}{\multicolumn{2}{|c|}{$\begin{array}{l}36.4 \pm 7.8 \\
10.3 \pm 1.8^{*} \\
21.7 \pm 3.5 \\
\end{array}$}} & \multirow{3}{*}{\multicolumn{2}{|c|}{$\begin{array}{l}4.60 \pm 0.52 \\
3.27 \pm 0.24 \\
4.29 \pm 0.67 \\
\end{array}$}} & \multirow{3}{*}{\multicolumn{2}{|c|}{$\begin{array}{l}3.19 \pm 0.15 \\
1.74 \pm 0.36^{*} \\
2.79 \pm 0.33\end{array}$}} & \multirow{3}{*}{\multicolumn{2}{|c|}{$\begin{array}{l}1.25 \pm 0.14 \\
1.19 \pm 0.34 \\
1.02 \pm 0.10 \\
\end{array}$}} & \multirow{3}{*}{\multicolumn{2}{|c|}{$\begin{array}{l}3.39 \pm 0.25 \\
2.79 \pm 0.03 \\
2.78 \pm 0.14\end{array}$}} & \multirow{3}{*}{\multicolumn{2}{|c|}{$\begin{array}{l}4.66 \pm 0.62 \\
2.76 \pm 0.29 \\
3.12 \pm 0.22 \\
\end{array}$}} & \multirow{3}{*}{\multicolumn{2}{|c|}{$\begin{array}{l}2.20 \pm 0.30 \\
0.91 \pm 0.22 * \\
1.86 \pm 0.18 \\
\end{array}$}} \\
\hline & Fructose & & & & & & & & & & & & & & & & & & \\
\hline & Glucose & & & & & & & & & & & & & & & & & & \\
\hline \multirow{3}{*}{ Female } & Control & \multirow{3}{*}{\multicolumn{2}{|c|}{$\begin{array}{l}1.28 \pm 0.30 \S \\
2.28 \pm 0.41 \\
1.35 \pm 0.28 \S \\
\end{array}$}} & \multirow{3}{*}{\multicolumn{2}{|c|}{$\begin{array}{l}3.27 \pm 0.48 \S \\
4.57 \pm 0.90 \# \\
1.64 \pm 0.45 \S \\
\end{array}$}} & \multirow{3}{*}{\multicolumn{2}{|c|}{$\begin{array}{l}16.2 \pm 2.2 \S \\
16.4 \pm 2.4 \\
10.6 \pm 4.0 \S \\
\end{array}$}} & \multirow{3}{*}{\multicolumn{2}{|c|}{$\begin{array}{l}16.4 \pm 6.4 \S \\
30.4 \pm 10.2 \S \\
15.7 \pm 2.4 \S\end{array}$}} & \multirow{3}{*}{\multicolumn{2}{|c|}{$\begin{array}{l}2.92 \pm 0.36 \\
2.93 \pm 0.54 \S \\
2.03 \pm 0.52\end{array}$}} & \multirow{3}{*}{\multicolumn{2}{|c|}{$\begin{array}{l}1.15 \pm 0.12 \\
1.01 \pm 0.09 \\
0.71 \pm 0.21 \\
\end{array}$}} & \multirow{3}{*}{\multicolumn{2}{|c|}{$\begin{array}{l}2.26 \pm 0.02 \S \\
3.59 \pm 0.26^{*} \# \S \\
1.76 \pm 0.03 \S \\
\end{array}$}} & \multirow{3}{*}{\multicolumn{2}{|c|}{$\begin{array}{l}4.91 \pm 0.77 \\
4.70 \pm 1.02 \S \\
3.53 \pm 0.65 \\
\end{array}$}} & \multirow{3}{*}{\multicolumn{2}{|c|}{$\begin{array}{l}2.24 \pm 0.21 \\
2.51 \pm 0.23 \S \\
1.72 \pm 0.58 \\
\end{array}$}} \\
\hline & Fructose & & & & & & & & & & & & & & & & & & \\
\hline & Glucose & & & & & & & & & & & & & & & & & & \\
\hline \multicolumn{2}{|c|}{ 2-way ANOVA } & $\mathrm{p}$ & $\eta 2$ & $\mathrm{p}$ & $\eta 2$ & $\mathrm{p}$ & $\eta 2$ & $\mathrm{p}$ & $\eta 2$ & $\mathrm{p}$ & $\eta 2$ & $\mathrm{p}$ & $\eta 2$ & $\mathrm{p}$ & $\eta 2$ & $\mathrm{p}$ & $\eta 2$ & $\mathrm{p}$ & $\eta 2$ \\
\hline & $\mathrm{G}$ & $<0.001$ & 0.661 & 0.002 & 0.326 & 0.032 & 0.170 & $<0.001$ & 0.564 & 0.956 & 0.000 & 0.182 & 0.065 & 0.001 & 0.371 & 0.251 & 0.054 & 0.042 & 0.156 \\
\hline & $\mathrm{D}$ & $<0.001$ & 0.469 & 0.041 & 0.225 & 0.018 & 0.276 & 0.755 & 0.024 & 0.127 & 0.147 & 0.120 & 0.146 & $<0.001$ & 0.587 & 0.138 & 0.152 & 0.148 & 0.142 \\
\hline & GxD & $<0.001$ & 0.653 & 0.003 & 0.379 & 0.010 & 0.306 & 0.258 & 0.111 & 0.048 & 0.208 & 0.629 & 0.034 & $<0.001$ & 0.632 & 0.210 & 0.122 & 0.027 & 0.250 \\
\hline
\end{tabular}

Relative target gene mRNA levels were measured by Real Time PCR, as explained in Materials and Methods, normalized to Rps29 levels and expressed in arbitrary units (a.u.). Data are mean \pm SE from 5-6 litters analyzed by two-way ANOVA, followed by Bonferroni's post hoc test. The significant effects of gender $(\mathrm{G})$, diet $(\mathrm{D})$ and their interaction $(\mathrm{GxD})$ were tested by two-way ANOVA and $\mathrm{p}$ value and $\eta 2(\mathrm{i} . \mathrm{e}$. the proportion of the total variance that is attributed to the corresponding effect) are shown. Post hoc analysis is indicated by $* p<0.05$ versus control group; \# $\mathrm{p}<0.05$ fructose versus glucose group; and $\S \mathrm{p}<0.05$ females versus males. 